\section{Around the world in eighty years}

\section{Harriet Guest}

Voyage into Substance: Art, Science,

Nature and the Illustrated Travel

Account, 1760-1840.

By Barbara Maria Stafford.

MIT Press: 1984. Pp.645. \$39.95,

£41.75.

FroM its foundation in 1660 the Royal Society was aware of the capital value of the "Philosophical stock" accumulated by "Voyages into all parts of the World". Following the invention of a reliable marine chronometer, the later eighteenth century saw a proliferation of voyages (and land expeditions) from Europe, one of whose aims was the garnering of further philosophical stores. This aspect of exploration and travel accounts as investigations and surveys of nature forms the subject of Professor Stafford's Voyage into Substance.

The book is, as its title suggests, a journey into a considerable range of subject matter: Professor Stafford discusses and refers to a mass of accounts, and an almost overwhelming variety of locations, ranging from the Sahara to the Arctic, from the microscopic to the planetary, from the mine shaft to the balloon. Almost inevitably, however, this vast range poses problems of organization and method. The author argues that the diverse representations of nature that fall within the scope of her study are unified as expressions of the "scientific gaze". This gaze is achieved through a willed act of seeing, which somehow voluntarily denudes itself of cultural content or accretions, as "scientific scrutiny recaptured the innocent eye of the archetypal encounter with the earth". She claims that "scientific perspicacity... inaugurated a new visual habit of plainness or real transparency", and disclosed a nature which declared its own history and meaning. This innocent vision finds its

clearly invite us to see it as more than an object of scientific scrutiny. But Professor Stafford comments only on the "probing scrutiny" of the artist's gaze, and indeed almost never refers to the interpretative functions of human figures and compositional structures in landscapes. She quotes Georg Forster's intention "to throw more light upon the nature of the human mind, and to lift the soul into that exalted station, from whence the extensive view must justify the ways of God to man...", and its triple literary allusion to Pope, Johnson and Milton indicates that the aims of his account are not purely those of science as she has defined it, and that his language is neither plain nor transparent.

For Professor Stafford, science is the "recording of phenomena stripped of human history". This may have been the aim of some travellers and of most explorers, but it can hardly be said that they achieved it, unless, like Professor Stafford, we take the will for the deed. example, William Hamilton illustrated the eruption of Vesuvius, he included in his aquatints some Neapolitan spectators of the event, and their expressive figures

Harriet Guest is a Research Fellow at King's College, Cambridge.

\section{Separating out}

\section{C.S.G. Phillips}

\section{Contemporary Practice of}

Chromatography.

By Colin F. Poole and Sheila A.

Schuette.

Elsevier: 1984. Pp.708. Dfl.159, \$61.25.

THIs book is, in effect, a highly complex and competent review of the present state of the art in the techniques of gas chromatography, high-performance liquid chromatography and high-performance thin-layer chromatography. Little space is wasted on the history of chromatography, on the wide variety of chromatographic methods that have been devised but are now infrequently used, or on the applications of chromatography other than for

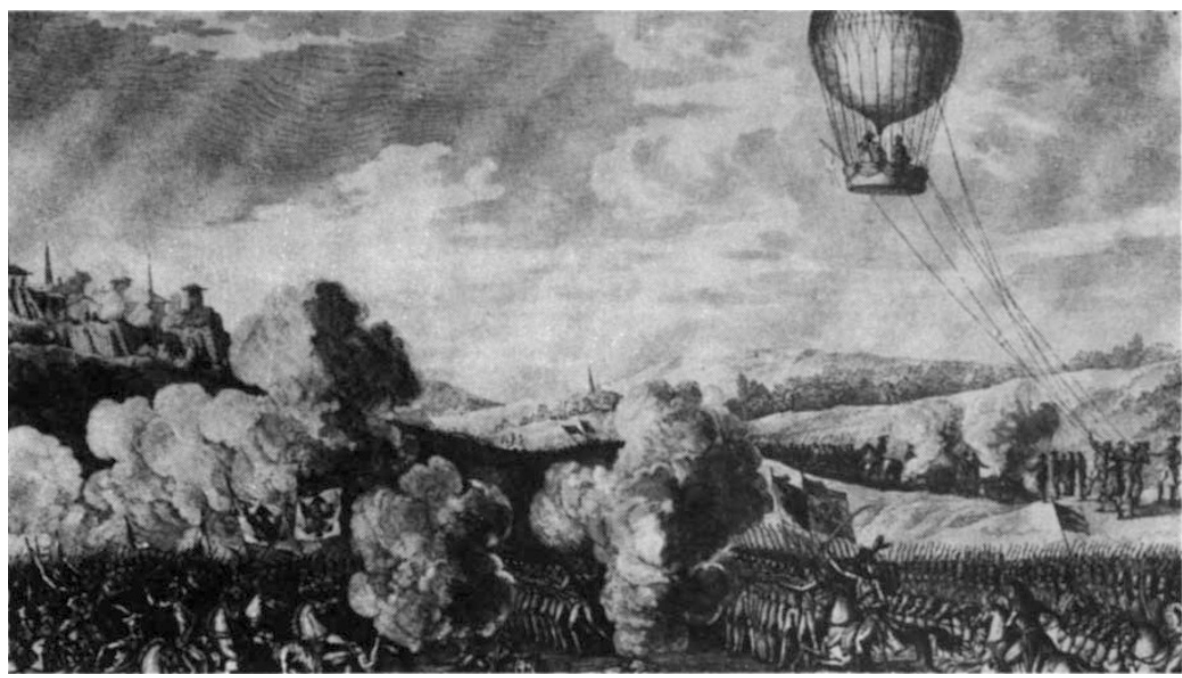

View from above - the Battle of Fleurus, 1793-94. Taken from Voyage into Substance.

analysis or preparative work. There is no reference to the various abstracting services available, or any general guide to the literature, while the wide use of computers with chromatographic instruments is only touched upon.

Where the book excels is in its attention to all the particular practical details of operating modern efficient chromatographic systems. It contains a mass of useful and critically considered information, backed by extensive bibliographies. There are two long, extremely helpful and illuminating chapters on the preparation of samples for chromatography and on "'hypenated" methods (such as mass spectrometry, Fourier transform infrared and nuclear magnetic resonance) for the identification of components after they have been separated by the chromatographic column. Contemporary Practice of Chromatography will surely prove to be a most valued guide and source of reference for all practising chromatographers.

The beginner, however, will not find it an easy book to read; for all its many virtues, it will not serve as a general introduction to the subject. The reader is expected to know too much, technical terms are frequently used without explanation, and even when explanations are provided they are sometimes difficult to find and to follow (the index is quite inadequate). Further, the general introduction is not always convincing: for example, on page 31 alone I found four statements with which I would take issue. So although this book provides a mine of information, clearly it is one where some hard digging is required.

C.S.G. Phillips is a Lecturer in the Department of Inorganic Chemistry, University of Oxford. 